\title{
Análise técnico-tático no contexto de igualdade numérica no futsal baseado em jogos conceituais.
}

Isaac Aparecido C. R. dos Santos ${ }^{\star}$, Renê A. Ribeiro, Samuel Bento da Silva, Alcides J. Scaglia, Milton S. Misuta.

\section{Resumo}

O esporte futsal é uma modalidade que pertence à família de jogos de bola com os pés. Neste contexto, foi analisar as possibilidades técnico-táticas no jogo de futsal no contexto de igualdade numérica nas situações de $4 \times 4$, baseado em jogos conceituais que possuem regras com bonificação. Nos jogos realizados, as ações relativas à estrutura ofensiva (drible+progressão; pivô+jogada ofensiva) e defensiva (desarme) ocorreram em maior quantidade independentemente do tipo de jogo. No grupo dos jogos GB-1 e GB-2, com a inclusão de regras: a) no ataque, houve aumento na quantidade das ações ofensivas incluídas; b) na defesa, verificamos a diminuição na quantidade de ações.

\section{Palavras-chave:}

Futsal, jogos conceituais, jogos coletivos.

\section{Introdução}

O futsal é uma modalidade que pertence à família de jogos de bola com os pés (Scaglia, 2009). Neste contexto, verifica-se a necessidade de se estudar o jogo considerando as situações que induzam à ruptura ou desequilíbrio na estrutura ofensiva e defensiva (Garganta, 2001), e o jogo como situação de busca de muitas e variadas metas (Garganta, 2001). O objetivo foi analisar as possibilidades técnico-táticas no jogo de futsal no contexto de igualdade numérica nas situações de $4 \times 4$, baseado em jogos conceituais de regras com bonificação.

\section{Resultados e Discussão}

Participaram do estudo, estudantes universitários, do sexo masculino. Divididos em grupos com 3 jogos e tempo de 5 minutos:

Grupo controle (GB): regras oficiais.

Grupo dos jogos com bonificação 1 (GB-1): acréscimo de regras funcionais (defesa: 1-pressão; 2recomposição. ataque: 1-passe longo; 2triangulação/tabela um dois).

Grupo dos jogos com bonificação 2 (GB-2): acréscimo de regras funcionais (Defesa: 1 -influenciar a passividade; 2-interceptar + domínio; 3-desarme; 4pressão; 5-defesa forçar o chute sem direção; 6defesa+lançamento; 7-recomposição. Ataque: 1lançamento 2-passe longo 3- triangulação/tabela um dois; 4-drible+progressão; 5-pivo+jogada ofensiva; 6assistência; 7-gol).

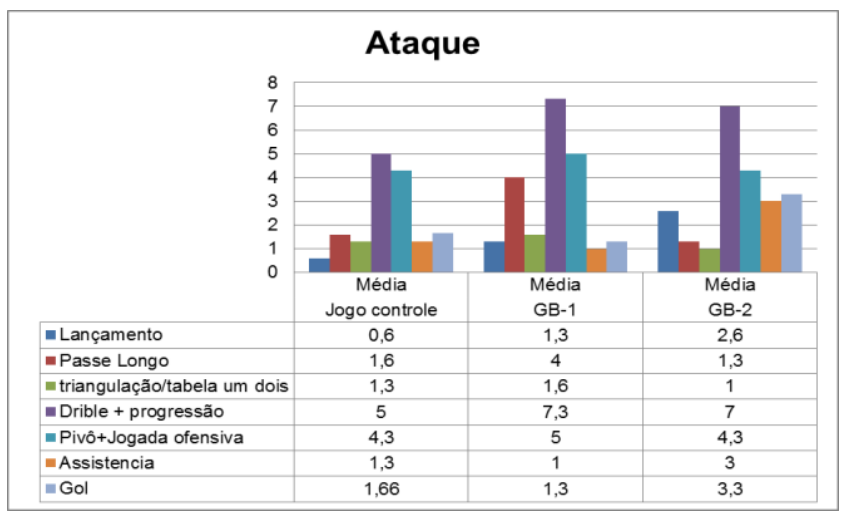

Figura 1. Distribuição das ações no ataque.

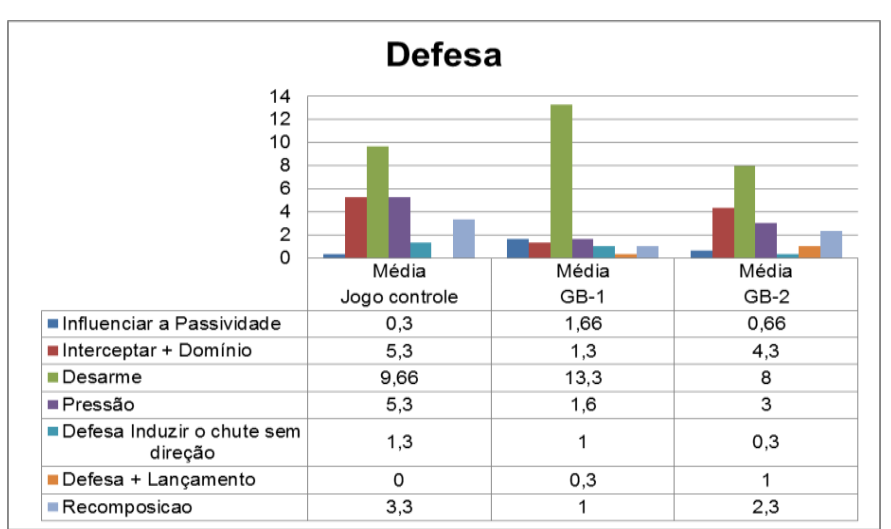

Figura 2. Distribuição das ações na defesa.

\section{Conclusões}

Nos jogos, as ações relativas à estrutura ofensiva (drible+progressão; pivô+jogada ofensiva) e defensiva (desarme) ocorreram em maior quantidade independentemente do tipo de jogo.

No grupo dos jogos GB-1 e GB-2, com a inclusão de regras:

a) no ataque, houve aumento na quantidade das ações ofensivas incluídas;

b) na defesa, verificamos a diminuição na quantidade de ações.

\section{Agradecimentos}

$\mathrm{CNPq} / \mathrm{PIBIC}$ pelo financiamento do projeto de pesquisa e LABIN - Laboratório de Biomecânica e Instrumentação.

1 - Lucas Leonardo, Alcides José Scaglia, Riller Silva Reverdito. O ensino dos esportes coletivos: metodologia pautada na família dos jogos. Revista Motriz, vol. 15, n. $2,236-246,2009$.

2 - GARGANTA. J. A análise da performance nos jogos desportivos. Revisão acerca da análise do jogo. Revista Portuguesa de Ciências do Desporto, vol. 1, $\mathrm{n}^{\circ}$ $1,57-64,2001$. 